\title{
Alteration Processes and Deterioration Phenomena of Faience Tiles in the Complex of King Djoser at Saqqara, Egypt
}

\author{
Fatma S. Madkour ${ }^{1}$ Mohamed K. Khallaf 2 \\ 1 Conservation Dept. Faculty of Fine Arts, Minia University, Minia, 61519, Egypt. \\ ${ }^{2}$ Conservation Dept. Faculty of Archaeology, Fayoum University, Fayoum, 63521 , Egypt. \\ m_kamal555@yahoo.com
}

\begin{abstract}
The Complex of King Djoser (2667-2648 BC) at Saqqara was the earliest stone building of its size in the world. Some of the walls of the substructure of the Step Pyramid and the so-called "Southern Tomb" were covered with panels of blue-green faience tiles. The present work aims to study causes of decay the faience tiles which coated Southern Tomb of Step Pyramid. Investigations and analytical techniques including scanning electron microscopy combined with energy-dispersive $\mathrm{X}$-ray microanalysis (SEM/EDX), X-ray diffraction (XRD), X-ray florescence (XRF) and polarizing microscopy were used. Results show that body of faience tiles contains high ratio of silicon oxide $\mathrm{SiO}_{2}$ and low amounts of alkaline oxides $\left(\mathrm{Na}_{2} \mathrm{O}, \mathrm{MgO}\right)$, copper was used to obtain the blue colour in an oxidizing atmosphere and fixing mortar of faience tiles consists mainly of calcite, quartz, gypsum, in addition to halite. High content of moisture and crystallization of salts mainly halite salt were the main factors of faience tiles degradation.
\end{abstract}

Keywords: Alteration processes; Faience tiles; Step Pyramid; Mortars.

eISSN 2398-4295 @ 2018. The Authors. Published for AMER ABRA cE-Bs by e-International Publishing House, Ltd., UK. This is an open-access article under the CC BY-NC-ND license (http://creativecommons.org/licenses/bync-nd/4.0/). Peer-review under responsibility of AMER (Association of Malaysian Environment-Behaviour Researchers), ABRA (Association of Behavioural Researchers on Asians) and cE-Bs (Centre for EnvironmentBehaviour Studies), Faculty of Architecture, Planning \& Surveying, Universiti Teknologi MARA, Malaysia.

DOI: http://dx.doi.org/10.21834/ajbes.v3i9.58 


\subsection{Introduction}

Faience, which consists of a ground quartz or quartz sand body coated with a sodarich glaze was first produced in both Egypt and the Near East as early as 4th millennium BC. This material was used to produce bowls and tiles as well as small objects such as amulets, beads, rings and scarabs (Tite et al., 2007). In Egypt the earliest surviving use of Egyptian blue faience tiles was possibly in the painting from tomb 3121 at Saqqara, which is dated to the reign of Ka-sen who was the last king of the 1 st Dynasty (2900 BC) (Hatton et al., 2008). However, the use of Egyptian blue frit in Egypt only became widespread by the 4th Dynasty $(2600 \mathrm{BC})$ and continued through until the Ptolemaic-Roman period (Tite et al., 2007; Hatton et al., 2008). Comparison of the microstructures of the ancient faience samples suggest that frit cakes are the primary product and that these were ground to produce the powder and then moulded to shape and refried to produce the vessels and beads (Hatton et al., 2008). Egyptian blue frit is a multicomponent material that was produced by firing a mixture of crushed quartz or sand with small amount of lime, a copper compound and alkali flux (natron or plant ash) to a temperature in the range 850-1000 ${ }^{\circ} \mathrm{C}$. (Hatton et al., 2008; La Delfa et al., 2008). The earliest Egyptian pyramids were step pyramids (Fig. 1).

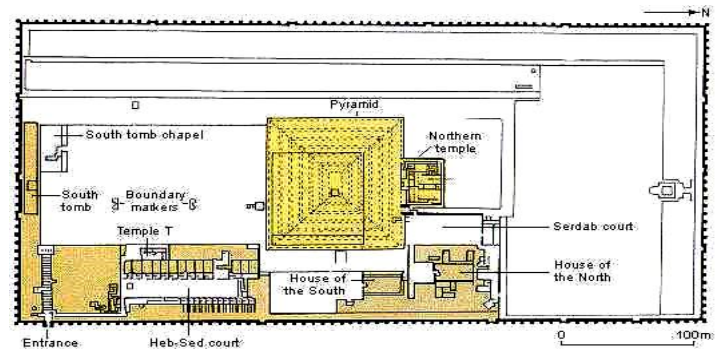

Fig. 1 shows the complex of king Djoser at Saqqara.

During the Third dynasty of Egypt, the architect Imhotep built Egypt's first step pyramid, the Pyramid of king Djoser at Saqqara by building a series of six successively smaller mastabas (an earlier form of tomb structure) one on top of another (fig. 2). Faience tiles were used to cover some of the walls of the substructures of the Step Pyramid and the so-called "South Tomb" (fig. 3), (fig. 4 a,b). The faience tiles suffer from many deterioration phenomena such as disintegration from stone supported walls, cracks, decay of mortars, crystallization of salts, missing parts from glazed layer besides loose and fall of many faience tiles from the walls. The rising damp in the supported walls and crystallization of soluble salts consider the main deterioration factors. The transformation of moisture involving variety processes such as absorption, evaporation, diffusion and capillarity as well as the surface tension of the liquid (Oliver, 1997; Charola 2000). Failure of faience tiles is most commonly water related where the ceramic units are highly susceptible to glaze cracking, spilling and material loosing (Wilson, 1984). Different analytical methods used to obtain useful information about determination the chemical composition and microstructure of the faience tiles in order to 
obtain important information about the raw materials used to produce the frit (Hatton et al., 2008; Tite et al., 2009). X-ray diffraction analysis (XRD), X-ray florescence (XRF) and scanning electron microscopy coupled with an energy dispersive $X$-ray microanalysis (SEM/EDX) used to study the changes in the microstructure compositions that have occurred in the faience tiles as a result of weathering, in addition to study the different deterioration aspects.

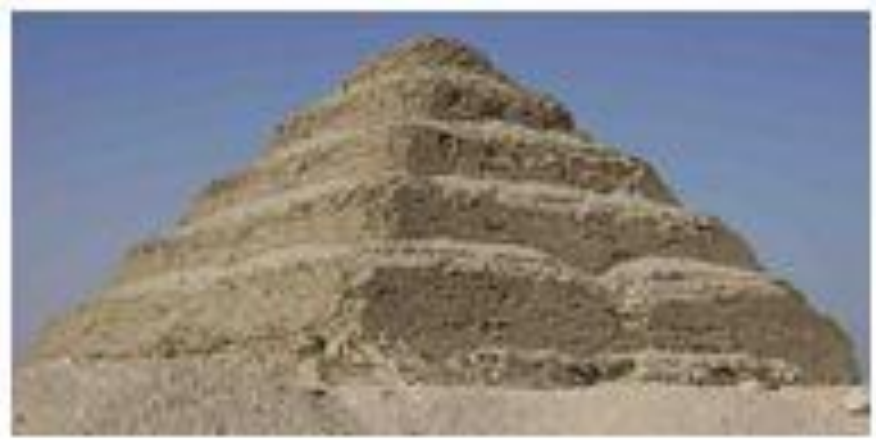

Fig. 2 shows the Step Pyramid at Saqqara

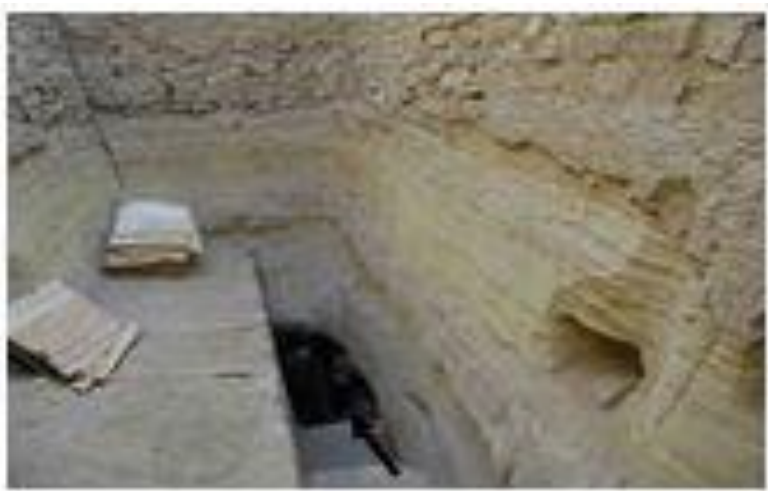

Fig. 3 shows entrance of South tomb of King Djoser at Saqqara .

\subsection{History of the Step Pyramid and the faience tiles}

Across the great court of the pyramid complex of Djoser (2667 - 2648 BC) the second king of the 3rd Dynasty, stands the Step Pyramid. It is believed to have been created by one man, called Imhotep. This complex represents the first major work in stone (Lehner, 1997). The superstructure of the Step Pyramid is six steps and was built in six stages (Siliotti, 1997). The symbolic king's inner palace decorated in blue faience tiles is much more complete than that of the pyramid. Three chambers of this substructure are decorated in blue faience tiles to imitate reed-mat facades, just like the pyramid (Martin, 2001). There are differences in dimensions of faience tiles but on average the dimensions of faience tiles are : $10 \mathrm{~cm}$ length, 
$6 \mathrm{~cm}$ width and $6 \mathrm{~mm}$ thickness.

\subsection{Description of faience tiles alteration}

The faience tiles suffer from high alteration including failure and fragile of the binding mortar which used to fix the faience tiles (fig. $5 \mathrm{a}, \mathrm{b}$ ). The glazed surfaces in some tiles subjected to high fragile and flaking off resulted in detachment them from bodies of the tiles (fig. 6 a, b), in addition to changing of the colours of faiences because of high moisture and crystallization of salts in the supported walls (fig. 7). Colored glazes suffer from crazing and spalling which appears as small blisters on the surfaces as well as some tiles subjected to cracking (fig. 8). Furthermore failure and fragile of the binding mortar between the tiles. All previous deterioration phenomena have resulted of high moisture in the walls, salt crystallization and finally human negligence of the maintenance these faiences which due to fall of many of them from the supported walls (fig. $9 \mathrm{a}, \mathrm{b}$ ).

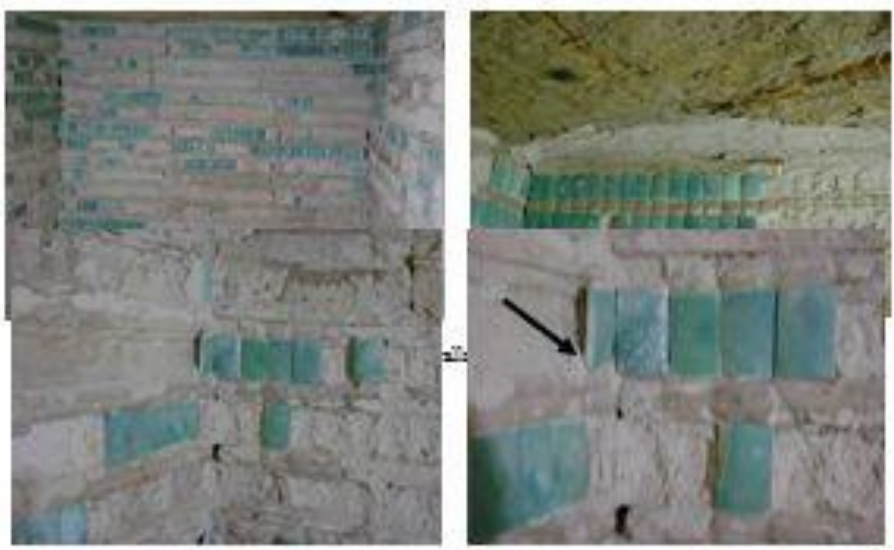

Fig. $5 a$, b shows fragile and flaking of some faience tiles.
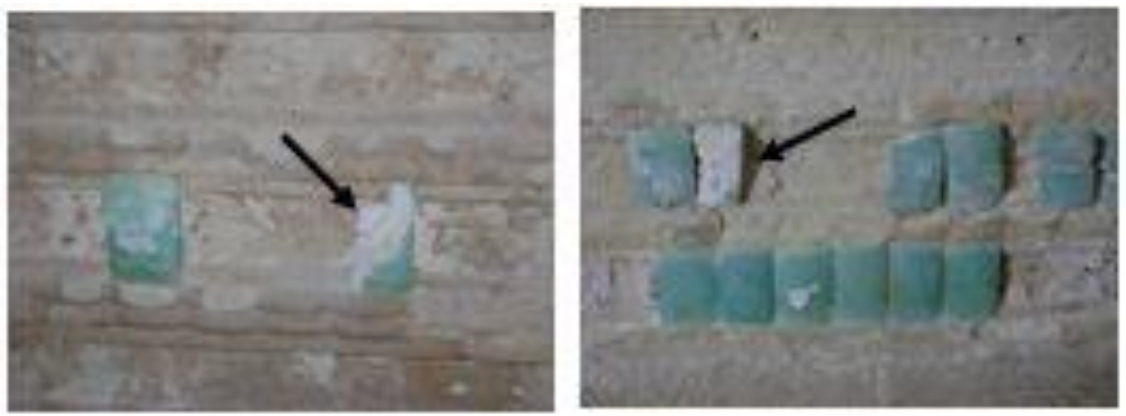

Fig. 6a, b shows missing of glazed layers and cracks in faience tiles. 


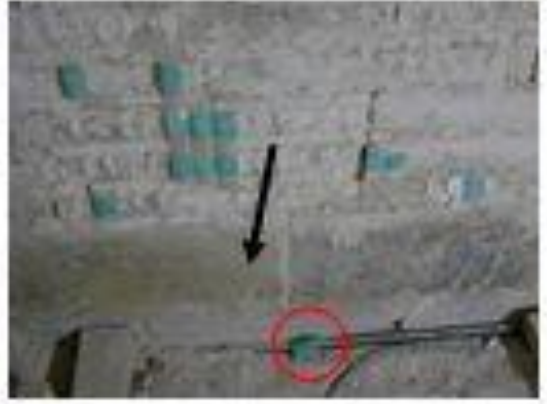

Fig. 7 shows high moisture and crystallization of salts in the supported walls
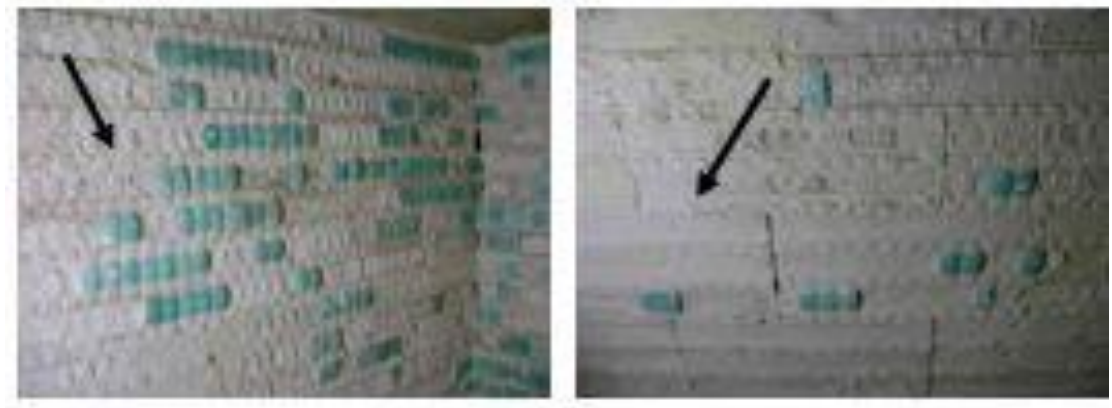

Fig. 9a, $b$ shows fall of many faience tiles from the supported walls.

\subsection{Methodology}

Different analytical techniques performed to characterize the faience tiles, mortars and stone walls to study the various types of alteration and degradation of these tiles. X-ray diffraction analysis (XRD) used to identify the mineralogical characterization of mortars and stone walls. X-ray diffractometer (Philips, PW 1840) with Ni-filtered CuKa radiation at operating conditions of $40 \mathrm{kV} / 30 \mathrm{~mA}$ and a scan speed of $2^{\circ}(2 \theta) / \mathrm{min}$. used for this purpose. Elemental analysis for the major and trace concentrations of faience tiles samples were determined by $X$-ray florescence (XRF; S4 XPLORER, Bruker at Dept. of Mineralogy and Petrology, University of Granada). Raw materials which used for the manufacturing and chemical composition of the faience tiles determined by using scanning electron microscopy (SEM). In addition to different samples of mortars and supported stone walls examined by using a variable pressure scanning electron microscope (VPSEM) Leo, 1430VP coupled with EDX microanalysis INCA 350, version 17, Oxford Instrument (Dept. of Mineralogy and Petrology, University of Granada). 


\subsection{Findings and Discussion}

\subsection{Polarizing microscope (PLM)}

Different samples of faience tiles and limestone supported walls were examined by using polarizing microscope. Cross sections of faience tiles shows that the components of faience tiles are a mixture of crushed quartz or sand with a small amount of lime. The quartz was appeared as angular grains and also we can see the pores and cracks through the body matrix which appear in black colour. A copper compound and alkali flux (natron or plant ash) appeared through the blue glazed layer which penetrated through porous body of the faience (fig. 10). Thin sections of limestone supported walls show that limestone consists of mainly fine-grained calcite crystals (biomicrite) besides presence of iron oxides, quartz, clay minerals and fossils (fig. 11).
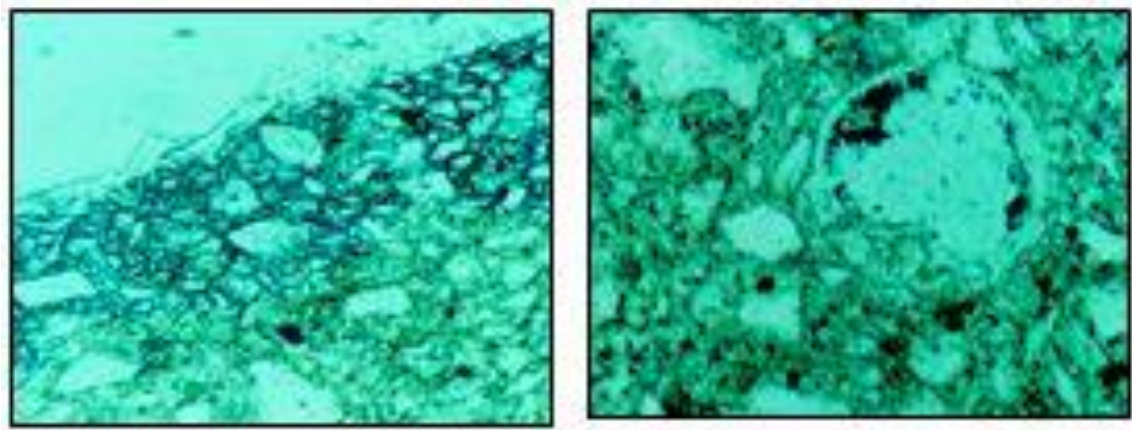

Fig. 10. Cross section photomicrographs showing mixture of crushed quartz which appeared as angular grains and also we can see the pores and cracks in the body matrix which appear in black colour
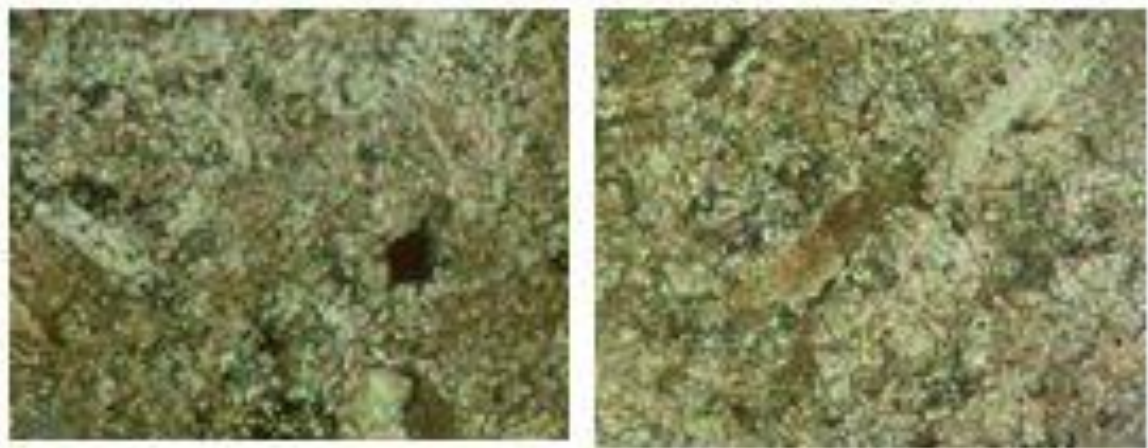

Fig. 11. Thin section photomicrographs showing iron oxides, clay minerals, fossil and grains of quartz in a mass ground of fine- grained calcite. $36 \mathrm{X}$ (C.N). 


\subsection{X-ray diffraction (XRD)}

\subsubsection{Bodies of faience tiles}

$X$-ray diffraction results of faience tiles samples shows that this sample consists of quartz mineral and calcite mineral, in addition to halite mineral as a salt (Fig. 12).

\subsubsection{Supported limestone walls}

X-ray diffraction data of supported walls sample shows that the sample consists of mainly calcite, dolomite, halite, quartz and gypsum (Fig. 13).

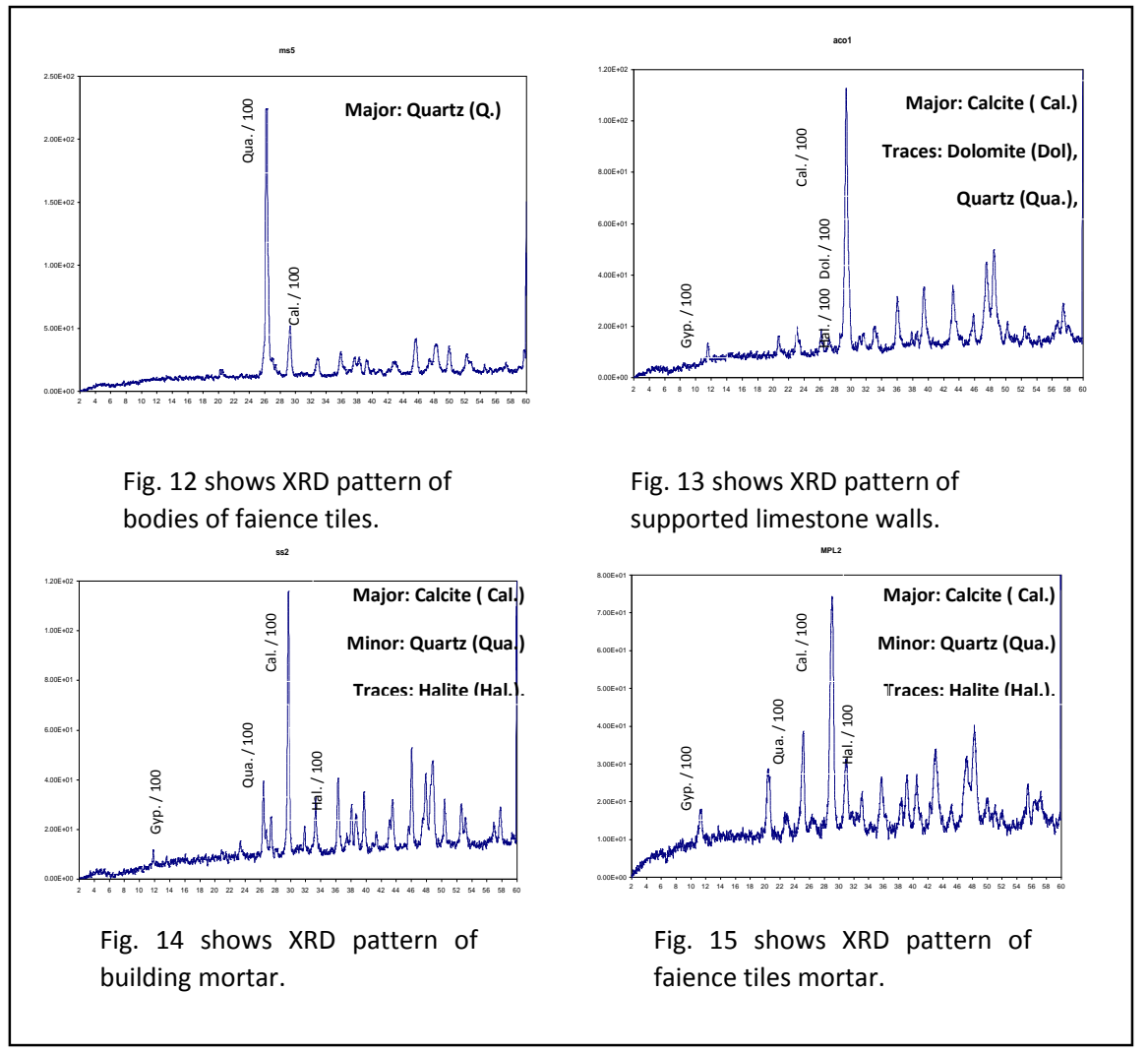

\subsubsection{Mortars}

Data of X-ray diffraction of building mortar shows that the sample consists of mainly calcite, quartz, gypsum, in addition to traces of halite as a salt (Fig. 14). Fixing mortar of faience tiles consists mainly of calcite, quartz, gypsum besides of halite mineral as a salt (Fig. 15). 


\subsection{X-ray florescence (XRF)}

The major and trace elements composition of tow samples from the body of faience were determined by X-ray florescence spectroscopy. The results obtained (table 1,2) showed that the body contains high ratio of silicon oxide $\mathrm{SiO}_{2}(91.19 \%)$, water $\mathrm{H}_{2} \mathrm{O}(5.5 \%)$. The alkaline oxides $\left(\mathrm{Na}_{2} \mathrm{O}, \mathrm{MgO}\right)$ are $.73 \%, .23 \%$ respectively whereas calcium oxide $\mathrm{CaO}$ is $(.88 \%)$. The result showed also that the body contains a few percent each of aluminium oxide $(.34 \%)$ and iron oxide $(.27 \%)$.

Tables 1, 2 show the XRF analysis results for body of faiences

Table 1.

\begin{tabular}{|c|c|}
\hline Compound Formula & $\begin{array}{c}\text { Concentration } \\
(\%)\end{array}$ \\
\hline $\mathrm{H}$ & 0.6155 \\
\hline $\mathrm{O}$ & 54.28 \\
\hline $\mathrm{Na}$ & 0.542 \\
\hline $\mathrm{Mg}$ & 0.139 \\
\hline $\mathrm{Al}$ & 0.181 \\
\hline $\mathrm{Si}$ & 42.63 \\
\hline $\mathrm{P}$ & 0.0593 \\
\hline $\mathrm{S}$ & 0.0285 \\
\hline $\mathrm{Cl}$ & 0.516 \\
\hline $\mathrm{K}$ & 0.0616 \\
\hline $\mathrm{Ca}$ & 0.633 \\
\hline $\mathrm{Ti}$ & 0.0199 \\
\hline $\mathrm{Mn}$ & 0.0043 \\
\hline $\mathrm{Fe}$ & 0.193 \\
\hline $\mathrm{Ni}$ & 0.00609 \\
\hline $\mathrm{Cu}$ & 0.0725 \\
\hline $\mathrm{Sr}$ & 0.00508 \\
\hline $\mathrm{Zr}$ & 0.00218 \\
\hline
\end{tabular}

Table 2.

\begin{tabular}{|c|c|}
\hline Compound Formula & $\begin{array}{c}\text { Concentration } \\
(\%)\end{array}$ \\
\hline $\mathrm{H}_{2} \mathrm{O}$ & 5.5 \\
\hline $\mathrm{Na}_{2} \mathrm{O}$ & 0.731 \\
\hline $\mathrm{MgO}$ & 0.23 \\
\hline $\mathrm{Al}_{2} \mathrm{O}_{3}$ & 0.342 \\
\hline $\mathrm{SiO}_{2}$ & 91.19 \\
\hline $\mathrm{P}_{2} \mathrm{O}_{5}$ & 0.136 \\
\hline $\mathrm{SO}_{3}$ & 0.0712 \\
\hline $\mathrm{Cl}$ & 0.516 \\
\hline $\mathrm{K}_{2} \mathrm{O}$ & 0.0742 \\
\hline $\mathrm{CaO}$ & 0.886 \\
\hline $\mathrm{TiO}_{2}$ & 0.0332 \\
\hline $\mathrm{MnO}$ & 0.0055 \\
\hline $\mathrm{Fe}_{2} \mathrm{O}_{3}$ & 0.276 \\
\hline $\mathrm{NiO}$ & 0.00774 \\
\hline $\mathrm{CuO}$ & 0.0908 \\
\hline $\mathrm{SrO}$ & 0.00601 \\
\hline $\mathrm{ZrO}_{2}$ & 0.00294 \\
\hline
\end{tabular}

\subsection{Scanning electron microscopy coupled with EDX}

Many samples including samples from the body of faience tiles, mortars and supported walls investigated and analyzed by scanning electron microscopy coupled with EDX microanalysis. Investigation by SEM of the body sample showed the erosion and disintegration of the faience by the salt crystallization (fig. 16a), whereas EDX analysis of the same location contains the elements of each chloride $(\mathrm{Cl})$ and sodium $(\mathrm{Na})$ with high ratio. This indicates 
that the faience tiles deteriorated by the crystallization of sodium chloride salt, in addition to leaching of the alkaline compounds from the core of faience to the surfaces (fig. 16b). The result analysis of the colored surface showed the presence of elements of silicon (Si), copper (Cu) (fig. 17a, b, c) and this indicate that a copper compound was used to obtained the turquoise blue colour in an oxidizing atmosphere (Hatton et al., 2008; Tite et al., 2009). The presence of sodium, magnesium and calcium elements indicate that weathering process was occurred according to (Oakley, 1989; Huisman et al., 2008; Tite et al., 2009) by action of water where the alkali ions $\left(\mathrm{Na}^{+}\right.$and $\left.\mathrm{K}^{+}\right)$are replaced by hydrogen ions $\left(\mathrm{H}^{+}\right)($fig. $17 \mathrm{~d})$. The mortar which used to fix the faience tiles have been analyzed and the results showed that it contains mainly both of chloride $(\mathrm{Cl})$ and sodium $(\mathrm{Na})$ elements and this indicate that this mortar contains high ratio of sodium chloride salt $\mathrm{NaCl}$ (fig. 18a, b, c, d). Regarding to the kind of building mortar used, the results were proved that it was consisted of lime and quartz (as aggregate), in addition to few amounts of sodium, aluminium, potassium and iron (fig. 19a,b). (Elert et al., 2002). The supported wall analysis showed that it is limestone where it contains mainly calcium (Ca), few contents of silicon (Si) and iron (Fe) (fig. 20a, b, c).
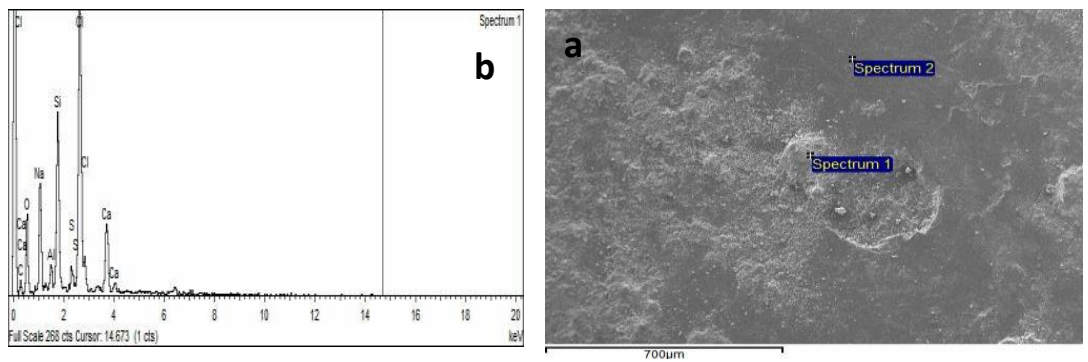

Fig. 16 a, b. show the SEM/EDX for the faience
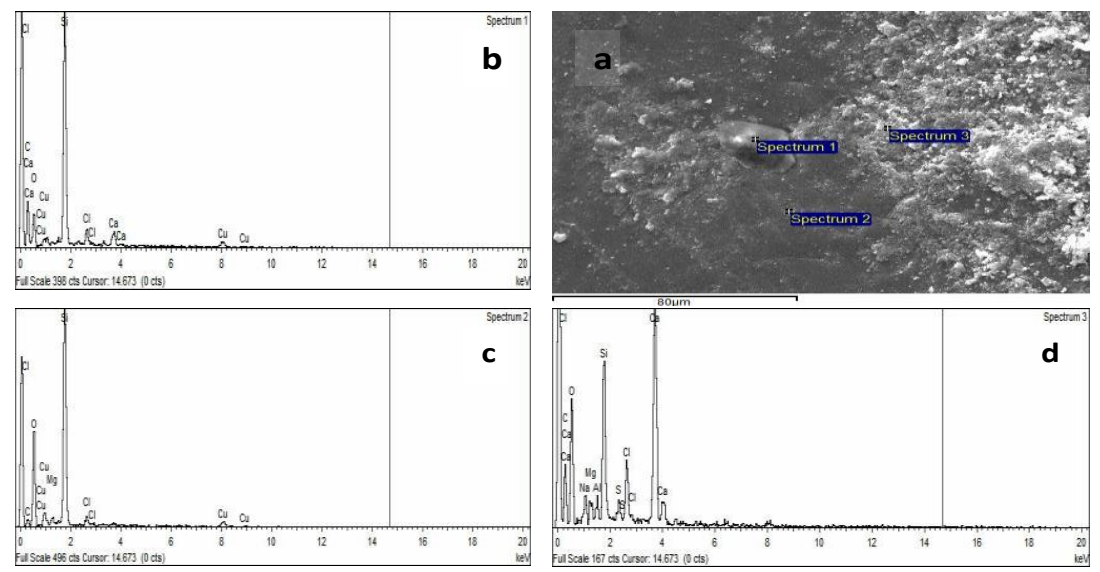

Fig. 17 a, b, c, d. show SEM/EDX results of colored faiences 
Madkour, F.S., \& Khallaf, M.K. / Asian Journal of Behavioural Studies (AjBeS), 3(9) Jan / Feb 2018 (p. 25-37)
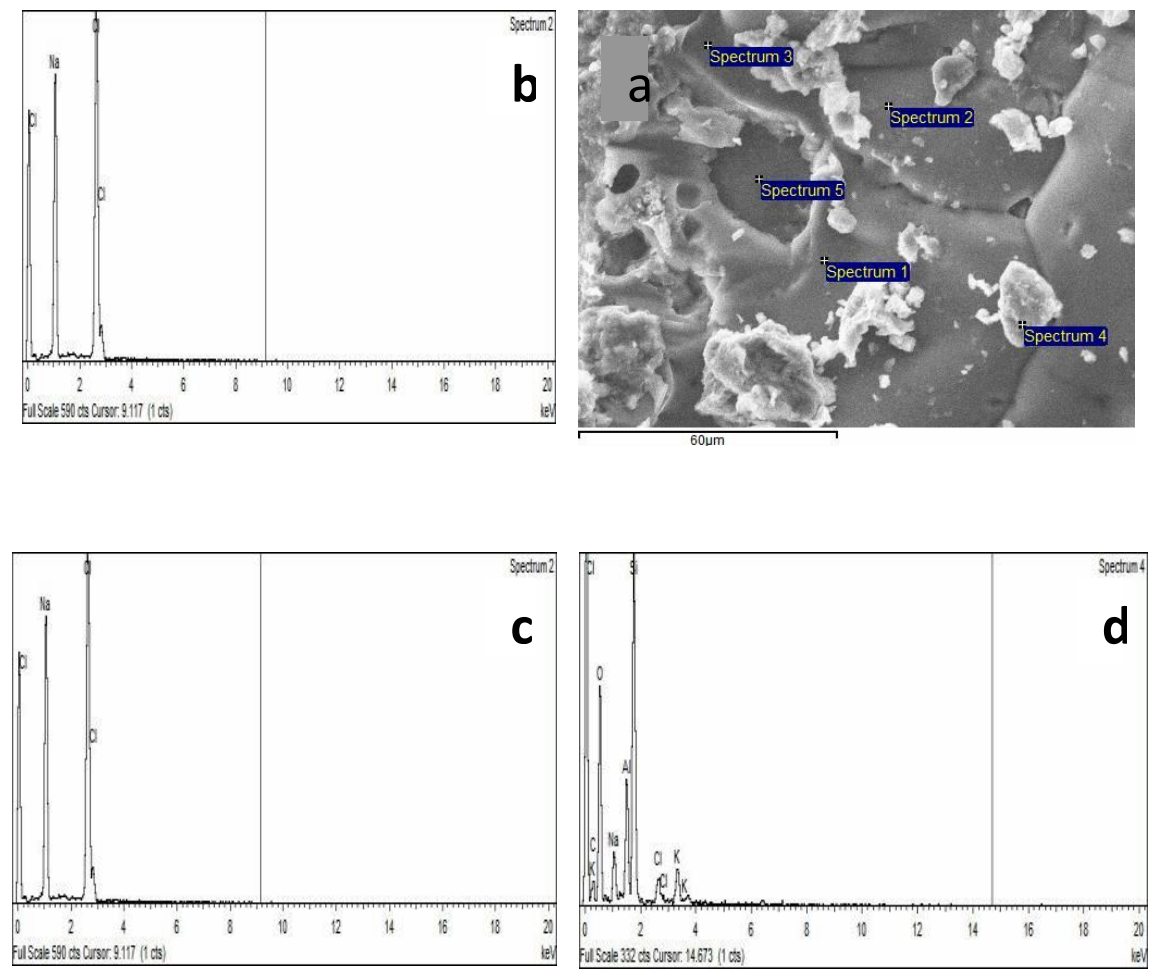

Fig. 18 a, b, c, d. show SEM/EDX results of mortar.
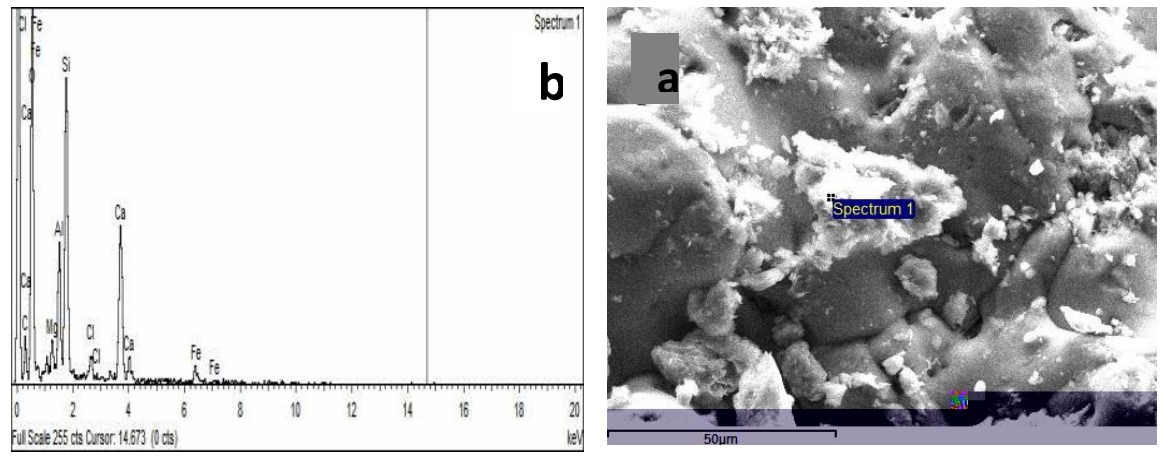

Fig. 19 a, b. show SEM/EDX results of building mortar. 

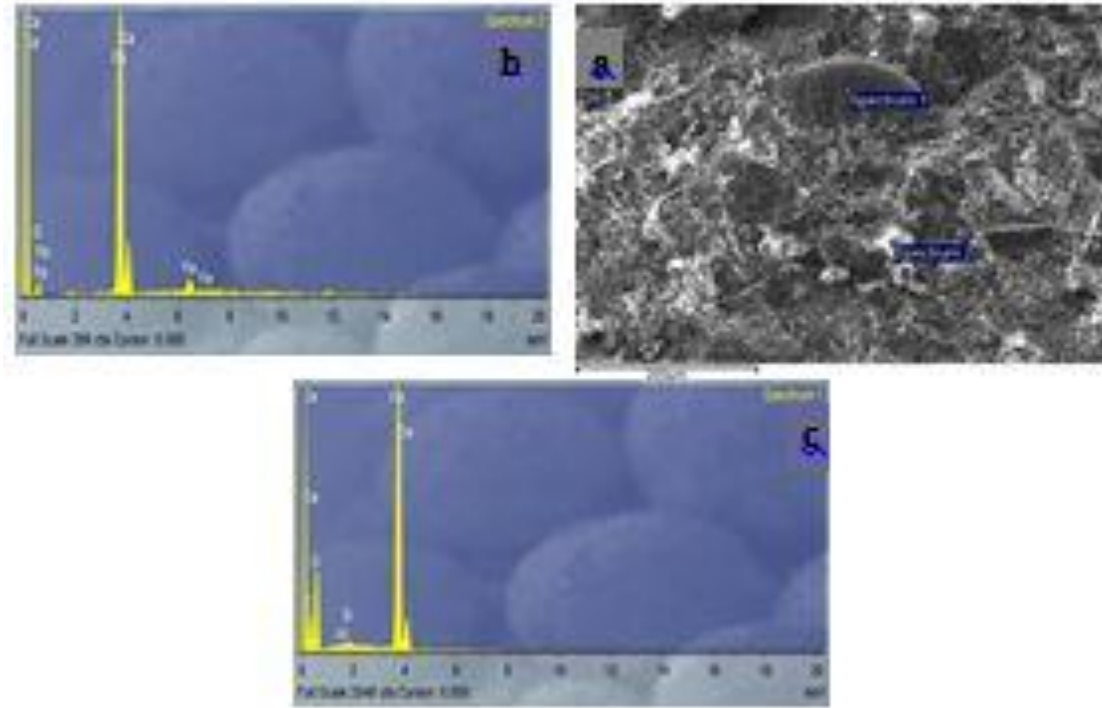

Fig. 20 a, b, c. show SEM/EDX results of supported walls.

\subsection{Causes of decay of faience tiles}

The results showed that the faience tiles suffered from high alteration because of rising damp in the supported walls and crystallization of soluble salts. Failure of faience tiles is most commonly water related where the units are highly susceptible to glaze cracking, spilling and material loosing. Also when a glass or glaze is subjected to weathering by action of water, the alkali ions $\left(\mathrm{Na}^{+}\right.$and $\left.\mathrm{K}^{+}\right)$are replaced by hydrogen ions $\left(\mathrm{H}^{+}\right)$and the glass network progressively breaks up. Thus, the silica glass structure is lost and replaced by amorphous layer so-called silica gel. In addition to leaching out of the alkalis, there are also some leaching out of the colorants which will no longer be present as ions but will have been deposited as fine amorphous or poorly crystalline compounds resulted in the change the chemical composition of faience surfaces (Schreiner et al., 1999; Huisman et al., 2008; Tite et al., 2009). Porous faience tiles can also deteriorate due to the presence of soluble salts within the body itself where the salts dissolve and re-crystallization. The binding mortars suffer from failure and fragile due to chemical alteration (Dotter, 2010) resulting of high content of moisture and crystallization of salts where the mortar has always been the key to the survival of ceramic tiles (Wilson, 1984). Limestone supported walls of faience tiles also suffer from salts crystallization. Salts may be carried into the stone with groundwater by capillary rise (Figueired et al., 2010) or may be dissolved from the mortar joints, or result from chemical reaction between atmospheric pollutants (especially $\mathrm{SO}_{2}$ ) and minerals (such as calcite $\left(\mathrm{CaCO}_{3}\right)$ in the limestone). If salts precipitated beneath the material of surface (a phenomenon called subflorescence or cryptoflorescence) severe damage can be induced (Espinosa-Marzal et al., 2010). The results determined also the human deterioration phenomena due to the human negligence which observed on the careless of the faience tiles 
at the tomb. Because of negligence and absence of the periodical maintenance and conservation procedures, many tiles fall of from their supported walls and sometimes lost completely.

\subsection{Conclusion}

$X$-ray florescence for the body of faience tiles showed that it contains high ratio of silicon oxide $\left(\mathrm{SiO}_{2}\right)$ and low amounts of alkaline oxides $\left(\mathrm{Na}_{2} \mathrm{O}, \mathrm{MgO}\right)$. X-ray diffraction results of the fixing mortar of faience tiles showed that it consists mainly of calcite, quartz, gypsum, in addition to halite (sodium chloride) as a salt and these results confirmed with the results obtained by EDX for the same sample. EDX microanalysis of the faience tiles colored surfaces determined that the presence elements of silicon (Si), copper $(\mathrm{Cu})$ which indicate that a copper compound was used to obtain the turquoise blue colour in an oxidizing atmosphere. The results determined that the faience tiles suffer from high degradation including failure and fragile of the binding mortar, fragile and flaking off the glazed surfaces as well as fall of many faience tiles from the supported walls. The binding mortars which used to fix faience tiles have always been the key to the survival of these tiles. The mortars suffer from failure and fragile due to chemical alteration resulting of high content of moisture and crystallization of salts mainly halite salt. The rising damp in the supported walls and crystallization of soluble salts consider the main deterioration factors of faience tiles. Finally this study will aid to carry out the conservation and maintenance works of these faience tiles at the future and will be useful for future researches of Egyptian faience tiles.

\section{Acknowledgement}

The authors wish to thank the specialists of Supreme Council of Antiquities at the Step Pyramid (Saqarra site) for kindly helpful and their aid to carry out some visits to the site to study and documentation the deterioration aspects of the faience tiles and also to get some samples to complete the research.

\section{References}

Charola, A. E. (2000). Salts in the deterioration of porous materials: An overview. Journal of the American Institute of Conservation, JAIC 39, 327-343.

Dotter, K. R. (2010). Historic lime mortars: potential effects of local climate on the evolution of binder morphology and composition. Geological Society of London. Special Publication No. 331, Edited by B. J. Smith, London. pp. 119-126.

Elert, K., Navarro, C. R., Pardo, E. S., Hansen, E., \& Cazalla, O. (2002). Lime Mortars for Conservation of Historic Buildings. Studies in Conservation, 47, 62-75.

Espinosa-Marzal, R. M. Et al., (2010). Mechanisms of damage by salt. Geological Society of London, Special Publication No. 331 Edited by B. J. Smith, London, 2010. pp. 61-78. 
Figueired, C., Et al., (2010). Pore structure and durability of Portuguese limestone: a case study. Geological Society of London, Special Publication No. 331 Edited by B. J. Smith, London. pp. 183-194.

Hatton, G. D., Shortland, A. J., \& Tite, M. S. (2008). The production technology of Egyptian blue and green frits from second millennium B.C. Egypt and Mesopotamia. Journal of Archaeological Science, 35, 1591-1604.

Huisman, D. J., Pols, S., Joosten, I., Van Os, B. J. H., \& Smit, A. (2008). Degradation processes in colorless Roman glass: cases from the Bocholtz burial. Journal of Archaeological Science, 35, 398-411.

La Delfa, S., Formisano, V., \& Ciliberto, E. (2008). Laboratory production of Egyptian faiences and their characterization. Journal of cultural Heritage, 9, e113-e116.

Lehner, M. (1997). The Complete Pyramids. New York. Thames and Hudson. 